\title{
Evaluation of Anti-biofilm Potential of Biosurfactant Extracted from Nocardia Species
}

\author{
Ali Javadi ${ }^{1}$, Mohamad Reza Pourmand ${ }^{1}$, Javad Hamedi ${ }^{2}$, Fatemeh Gharebaghi ${ }^{1}$, Zohre Baseri ${ }^{3}$, \\ Abbas Morovvati ${ }^{1}$, Razieh Mohammadzadeh ${ }^{1}$, Seyyed Saeed Eshraghi ${ }^{1}$ \\ ${ }^{1}$ Department of Pathobiology, School of Public Health, Tehran University of Medical Sciences, Tehran, Iran \\ ${ }^{2}$ Microbial Biotechnology Laboratory, Department of Microbiology, School of Biology, College of Science, University of Tehran, Tehran, Iran \\ ${ }^{3}$ Department of Microbiology, School of Medicine, Iran University of Medical Sciences, Tehran, Iran
}

Corresponding author: Seyyed Saeed Eshraghi, Department of Pathobiology, School of Public Health, Tehran University of Medical Sciences, Tehran, IR Iran; E-mail: esraghi1398@gmail.com; Tel.: +98-2188994823

Received: 17 May 2020 Accepted: 14 July 2020 Published: 30 June 2021

Citation: Javadi A, Pourmand MR, Hamedi J, Gharebaghi F, Baseri Z, Morovvati A, Mohammadzadeh R, Eshraghi SS. Evaluation of anti-biofilm potential of biosurfactant extracted from Nocardia species. Folia Med (Plovdiv) 2021;63(3):392-9. doi: 10.3897/folmed.63. e54386.

\section{Abstract}

Introduction: Bacterial natural products such as biosurfactants and surface-active agents are important compounds which exhibit many applications in the fields of medicine.

Aim: The aim of the present study was to isolate and identify Nocardia strains with high biosurfactant production and antibiofilm ability.

Materials and methods: In the present study, a biosurfactant producing Nocardia species was isolated and identified by a laboratory method. Nocardia species were initially screened and then tested for their ability to produce biosurfactant. The oil spreading test and the surface tension measurements showed that one strain was a biosurfactant producer. The strain with the best surface activity results was selected for further studies and identified by $16 \mathrm{~S}$ rRNA gene sequencing method. Fourier transform infrared spectroscopy (FTIR) and compositional analysis proved a biosurfactant structure.

Results: Oil spreading test and blue agar plate test confirmed biosurfactants and extracellular anionic glycolipids. E24\% assay using olive oil revealed strong emulsifying characteristic of the extracted biosurfactant with $100 \%$ emulsifying strength. FTIR spectrum indicated the presence of aliphatic hydrocarbon chain (lipid) along with the polysaccharide portion, confirming the glycolipid nature of the biosurfactant. The stability of the biosurfactant produced in different conditions was significant. Increasing concentration of BS significantly inhibited Pseudomonas aeruginosa biofilm.

Conclusions: N. coubleae can be a representative of the genus Nocardia for the production of biosurfactants with beneficial physicochemical properties.

\section{Keywords}

biofilms, isolation \& purification, Nocardia, surface-active agents, Pseudomonas aeruginosa

Copyright by authors. This is an open access article distributed under the terms of the Creative Commons Attribution License (CC-BY 4.0), which permits unrestricted use, distribution, and reproduction in any medium, provided the original author and source are credited. 


\section{INTRODUCTION}

Actinobacteria are an important source of secondary metabolites and a key group in the environmental cycle with the ability to decompose organic compounds and produce antibiotics. ${ }^{1}$ The genus Nocardia belonging to this family is found as saprophyte in a variety of soils. This genus has a very strong potential for decomposition of materials and production of secondary metabolites and extracellular compounds. ${ }^{2}$ Although some opportunistic species can lead to a disease in immunocompromised individuals, they are very important for the production of compounds such as antibiotics including nothramicin and new anthracyclines. ${ }^{3,4}$ The natural products of these bacteria are used in pharmaceutical, medical, environmental, and agricultural industries. ${ }^{5}$ Meanwhile, biosurfactants are among the bacterial extracellular products which have been taken into consideration in recent years. These compounds are less toxic than the chemosurfactants, they are biodegradable and environmentally friendly. ${ }^{6}$ Other advantages of these compounds include low irritancy, skin compatibility, greater foaming, and high sensitivity and specificity under different temperature and $\mathrm{pH}$ conditions as well as different salt concentrations. ${ }^{7}$ Various microorganisms have the ability to produce these compounds. Bacilli produce types of lipoproteins, where a variety of glycolipids are synthesized by pseudomonas and candida species. ${ }^{8}$ Finding species with a high ability to produce biosurfactants with unique properties and the use of these compounds in oil industry, medicine, pharmaceutical and food industry, and agriculture, have been the driving force to working on introduction of appropriate bacteria in this regard. ${ }^{9}$

\section{AIM}

The goal of this study was to introduce a species of genus Nocardia with the ability to produce biosurfactant and to evaluate the properties of the produced biosurfactant.

\section{MATERIALS AND METHODS}

\section{Isolation of Nocardia species}

One gram of soil sample was transferred to $10 \mathrm{ml}$ of sterilized water and shaken for 10 minutes. Following soil deposition, $1 \mathrm{ml}$ of supernatant was transferred to tubes containing $7 \mathrm{ml}$ of paraffin carbon free broth medium. After 4 weeks at $35^{\circ} \mathrm{C}$, the colonies grown on the paraffin surface were transferred to the nutrient agar medium and morphologically confirmed after growth. Lysozyme resistance test and partial acid-fast staining were used to confirm the genus Nocardia. Biochemical tests were used to phenotypic identification. ${ }^{10}$

\section{Biosurfactant assays}

\section{Production of biosurfactant}

Using production medium ( $\mathrm{g} / \mathrm{l}$ ) containing $30 \mathrm{ml}$ of olive oil, $0.46 \mathrm{~g}$ of $\mathrm{NH}_{4} \mathrm{NO}_{3}, 0.1 \mathrm{~g}$ of $\mathrm{KHPO}_{4}, 0.1 \mathrm{~g}$ of $\mathrm{MgSO}_{4}, 0.1 \mathrm{~g}$ of $\mathrm{CaCl}_{2}, 0.2 \mathrm{~g}$ of yeast extract, and $\mathrm{pH}=6$ was used for the biosurfactant production. For purification of the biosurfactant, the culture suspension was centrifuged at 15,000 rpm for 20 minutes, and the $\mathrm{pH}$ of the supernatant was adjusted to 2 with $\mathrm{HCl}(1 \mathrm{~N})$. After 15 minutes, chloroform:methanol (2:1) was added with the same volume of supernatant with the upper phase being separated. The solvent was removed by a rotary evaporator at $40^{\circ} \mathrm{C}$. Then, the biosurfactant was obtained and used for confirmatory tests and the physicochemical characteristics in subsequent stages of testing. ${ }^{11,12}$

\section{Oil spreading test (OST)}

To measure the surface tension reducing characteristic of the extracted biosurfactant, $50 \mathrm{ml}$ of distilled water was poured into plate and then $20 \mu \mathrm{l}$ of crude oil was placed on the water surface. Subsequently, $10 \mu$ l of biosurfactant was poured onto crude oil. The surface tension lowering characteristic led to the creation of a transparent zone and crude oil dispersion rate. The diameter of the zone was recorded in $\mathrm{cm} .{ }^{13}$

\section{Blue agar plate method}

The selective CTAB-methylene blue agar medium containing (g/l): glucose 20 , peptone 10 , beef extract 1 , CTAB 5 and methylene blue 0.02 , yeast extract 0.5 , and agar 17 with $\mathrm{pH} 7.2$, was used to detect the glycolipid and anionic nature of biosurfactant extracted. Accordingly, $30 \mu \mathrm{l}$ of supernatant solution was poured into $6-\mathrm{mm}$ wells with the plates placed in an incubator at $37^{\circ} \mathrm{C}$ for 72 hours. A dark blue zone formed around the well represented anionic biosurfactant. ${ }^{14}$

\section{Emulsification stability index (E24\%)}

The emulsifying activity of the biosurfactant was performed according to the Cooper and Goldenberg method. First, $15 \mathrm{ml}$ of the biosurfactant solution was added to 35 $\mathrm{ml}$ of olive oil and then vortexed for 2 minutes. After 24 hours, E24\% was obtained through dividing the emulsified phase by the total volume of solution multiplied by $100 \%{ }^{13}$

\section{Measurement of surface tension (ST)}

ST was measured using a tensiometer (Kruss GmbH, Germany) in accordance with the Wilhelm plate technique. The tensiometer was first calibrated with distilled water, and then the solution containing biosurfactant plus oil was read out with the device with the surface tension obtained based on $\mathrm{mN} / \mathrm{m}^{13}$ 


\section{FTIR spectral analysis}

FTIR device was used to determine the organic composition of the purified biosurfactant. The biosurfactant dried powder was used for this purpose. The dry biosurfactant was mixed with $\mathrm{KBr}$ and the readings were carried out within the range of $400-4000 \mathrm{~cm}^{-1}$ at a resolution of $8 \mathrm{~cm}^{-1}{ }^{15}$

\section{Stability of biosurfactant}

The stability of the extracted biosurfactant was determined using three variables: temperature, $\mathrm{pH}$, and salinity. A solution of $50 \mathrm{mg} / \mathrm{ml}$ of the biosurfactant was used for this purpose. The stability maintenance was tested within the temperature range of $20^{\circ} \mathrm{C}$ to $120^{\circ} \mathrm{C}$ within which the solution was exposed. After cooling and reaching room temperature, the OST test was used for the activity. The range from 2 to 9 was employed to test $\mathrm{pH}$ stability. Once placed within this range, the OST test was performed and the created zone was measured in $\mathrm{cm}$. A concentration of 0 to $35 \% \mathrm{NaCl}$ was used to assess the salinity conditions. The OST activity was measured as well. ${ }^{16,17}$

\section{Determination of antibiofilm activity}

In this method, biofilm inhibition was performed by biosurfactant. $180 \mu \mathrm{l}$ of Pseudomonas aeruginosa (ATCC 27853 ) suspension was absorbed 0.1 poured into the microtiter plate. After culturing for $24 \mathrm{~h}$, different concentrations of BS were added and incubated for $4 \mathrm{~h}$ at $37^{\circ} \mathrm{C}$. After incubation, wells were washed three times with $200 \mu \mathrm{L}$ sterile distilled water to remove non-adherent bacteria. The wells were kept in the room for 45 minutes and then added $200 \mu \mathrm{L}$ per well with $0.1 \%$ crystalline violet solution (v/v) in water for 45 minutes. The wells were then washed three times with $300 \mu \mathrm{l}$ of sterile distilled water. The dye provided by the adherent cells was dissolved in $200 \mu$ of $95 \%$ (v/v) ethanol. The absorbance of each well was measured at $595 \mathrm{~nm}$ using a microtiter ELISA reader. The percentage inhibition of biofilm activity was calculated using the following equation: [1 - (A595 of cells treated with BS/A595 of non-treated control cells)] $\times 100 .{ }^{18}$

\section{Molecular identification}

Chromosomal DNA was extracted using a simple boiling method, with PCR technique and 16s rRNA sequencing utilized for final identification at the species level and for phylogenetic analysis. After extracting the genomic DNA, the PCR process based on primers 27F (5'AGAGTTTGATCCTGGCTCAG3') and 1492R (5'- GGTTACCTTGTTACGACTT -3') and using Amplicon master mix with PCR temperature program of $94^{\circ} \mathrm{C}$ for 5 minutes, $94^{\circ} \mathrm{C}$ for 40 seconds, $55^{\circ} \mathrm{C}$ for 45 seconds, $72^{\circ} \mathrm{C}$ for 1 minute and $72^{\circ} \mathrm{C}$ for 10 minutes with 35 cycles, the reaction was terminated. Then, the PCR products were sent to Microsynth Co. in Switzerland for sequencing after electrophoresis and the observation of a suitable band of $1480 \mathrm{bp}$. The sequencing results were analyzed based on the NCBI site and the Mega7 software, and the phylogenetic tree was plotted. ${ }^{16}$

\section{RESULTS}

\section{Nocardia species identification}

Based on phenotypic and biochemical methods, the biosurfactant producing bacteria were identified where the results of gram-positive bacillus branched with gypsiferous white colonies were obtained. The partial acid-fast staining was used to differentiate them from streptomyces. In this method, Nocardia species was found to be partially acid fast. The Nocardia coubleae confirmed with lysozyme resistance and conventional biochemical tests.

\section{Biosurfactant assay}

\section{Oil spreading test (OST)}

The crude oil dispersion rate of the supernatant solution of targeted bacterial culture was found by recording the transparent zone $(6 \mathrm{~cm})$ diameter (Fig. 1A).

\section{Blue agar plate method}

The dark blue zone around the wells in the methylene blue agar plate indicates the production of anionic biosurfactant. The formation of extracellular anionic glycolipids has been confirmed in this test (Fig. 1B).

\section{Emulsification stability index (E24\%) and measurement of surface tension}

Measurement of the physicochemical properties of extracted biosurfactant with E24\% and surface tension assay revealed that the compound of interest had a surface tension lowering characteristic of $35 \mathrm{mN} / \mathrm{m}$. E24\% assay using olive oil indicated a strong emulsifying characteristic of the extracted biosurfactant with a $100 \%$ emulsifying strength.

\section{FTIR spectral analysis}

The analysis of the FTIR spectrum indicated the presence of aliphatic hydrocarbon chain (lipid) along with the polysaccharide portion, confirming the glycolipid nature of the biosurfactant. The absorption bands of $3200-3600 \mathrm{~cm}^{-1}$ exhibited the presence of free $\mathrm{OH}$ groups due to $\mathrm{H}$ bond with polysaccharides and absorption peak of 1640-1770 $\mathrm{cm}^{-1}$ indicating $\mathrm{C}=\mathrm{O}$ stretching vibration of carboxylic acid groups of lipid and fatty acids. The absorption peak of $2800-3040 \mathrm{~cm}^{-1}$ represents the $-\mathrm{CH}$ stretching vibration band (asymmetric stretching and symmetric stretching 


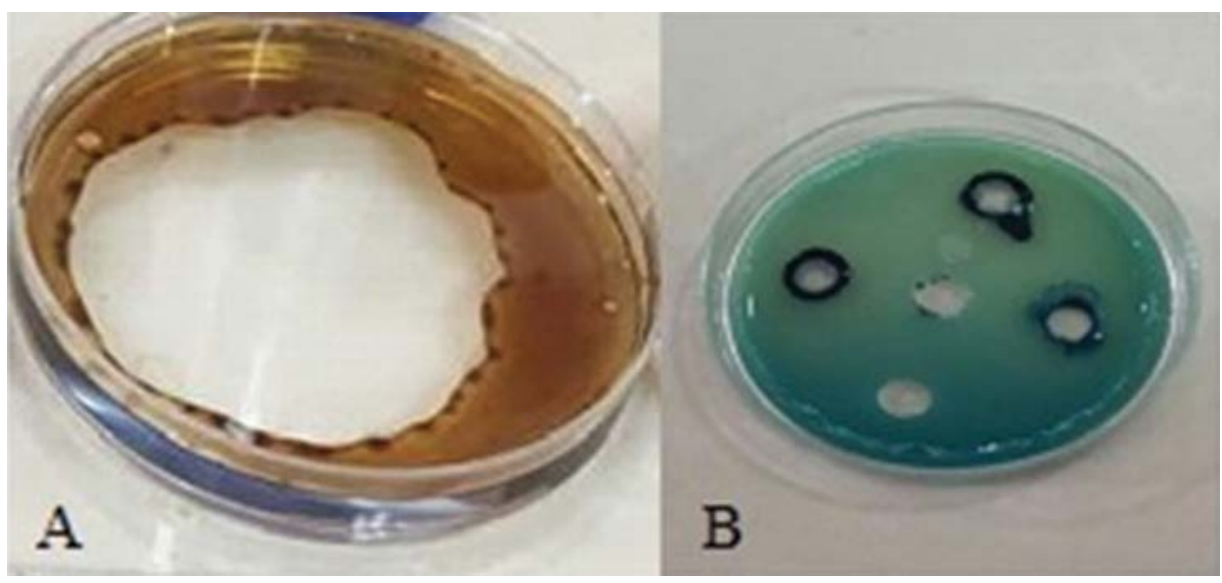

Figure 1. Oil spreading test (OST) to determine surfactant activity (A); Methylene blue agar plate test for anionic biosurfactant determination (B).

of $-\mathrm{CH} 2$ band) associated with sugar. The vibration of the alkyl groups was confirmed by the presence of the peak at $1385 \mathrm{~cm}^{-1}$. The absorption peak at $1115 \mathrm{~cm}^{-1}$ showed that the stretching band was related to carbon atoms with hydroxyl groups in the sugar structure, confirming the glycolipid nature (Fig. 2).

\section{Stability of the produced biosurfactant}

During stability tests under different temperature, $\mathrm{pH}$ and salinity conditions, the biosurfactant produced from Nocardia bacteria indicated that it was a relatively heat-resistant compound with a surface tension lowering characteristic at $120^{\circ} \mathrm{C}$. Temperature variations showed that the biosurfactant property of the extracted compound did not diminish with the temperature rise. Concerning acidic to alkaline $\mathrm{pH}$, it showed better neutral properties, thus reducing surface tension in acidic and alkaline range. Finally, in different conditions of salt concentration, the best activity was at zero concentration, while minimum activity was observed at $30 \% \mathrm{NaCl}$ concentration (Fig. 3).

\section{Antibiofilm effects}

To investigate BS antibiofilm effects, bacterial cells were grown to form biofilms and then treated with different concentration of BS. Increasing concentration of BS significantly inhibited the Pseudomonas aeruginosa biofilm. Treatment of biofilms at $200 \mu \mathrm{g} / \mathrm{ml}$ resulted in up to $85 \%$, with forced removal of the biofilm leading to disruption and indicating that the obtained effect was dose dependent (Fig. 4).

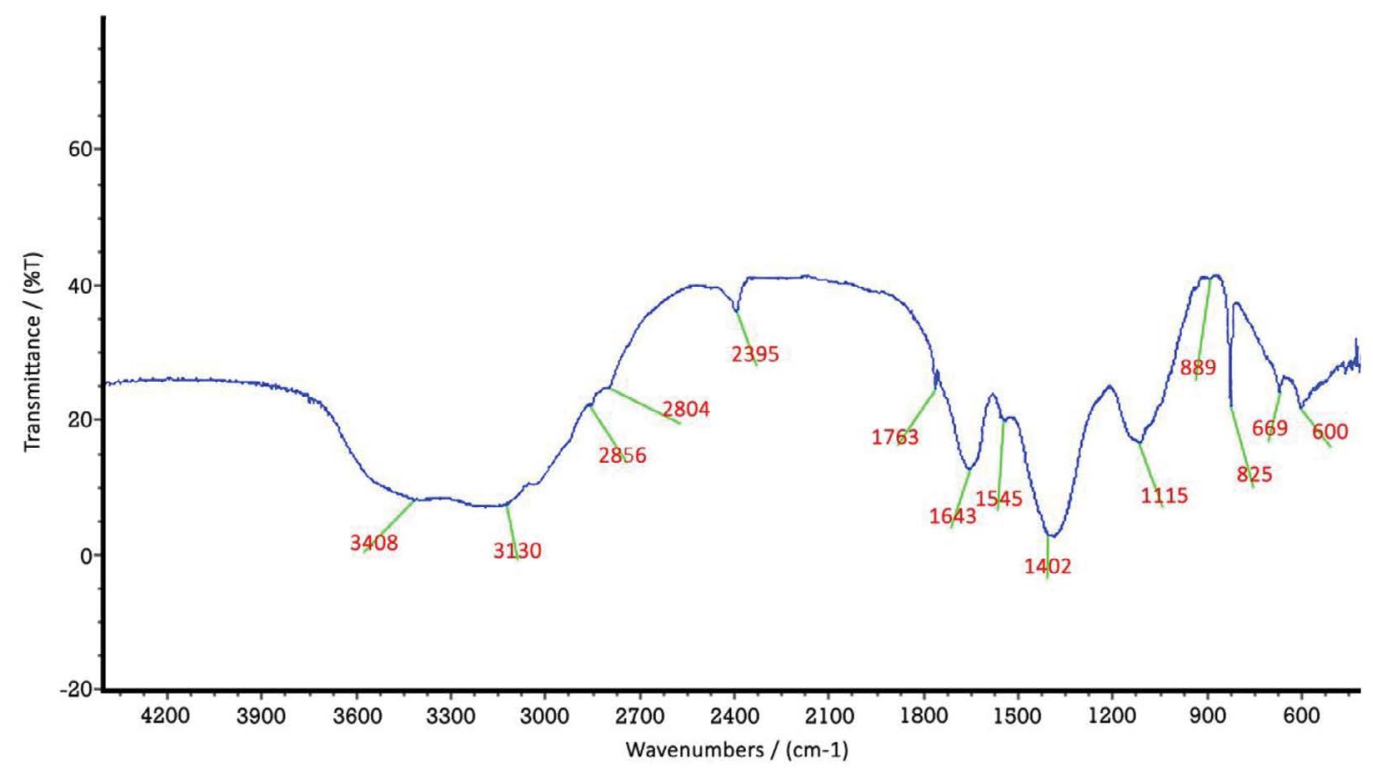



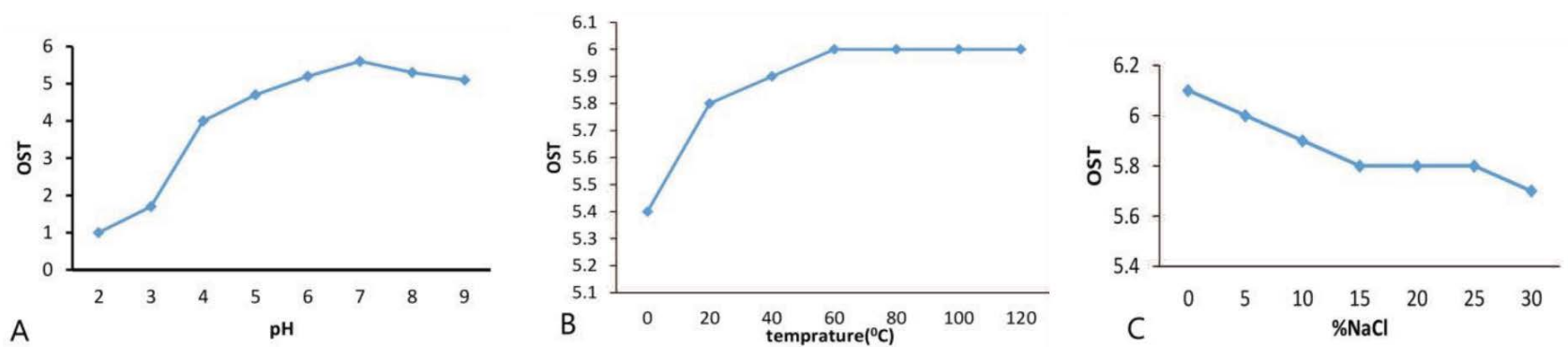

Figure 3. Stability of biosurfactants under different conditions: A (pH), B (temperature), C (salinity).

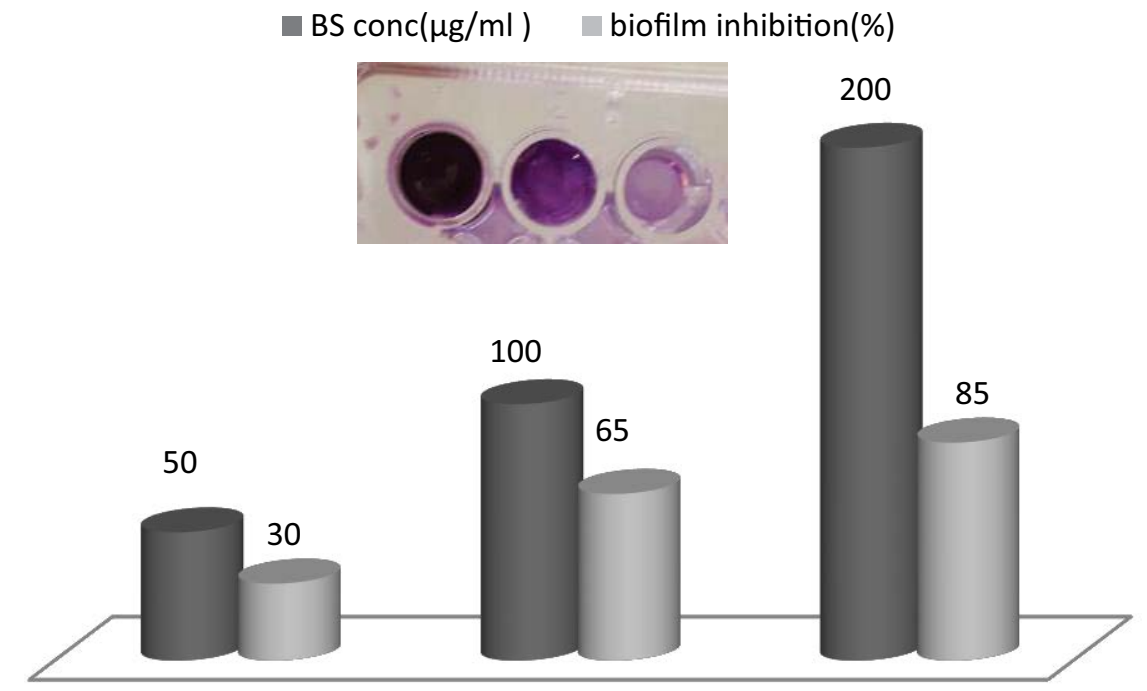

Figure 4. Effect of different concentrations of BS on biofilm inhibition.

\section{PCR and 16S rRNA sequence analysis}

The selected isolate was detected more precisely and phylogenetically by PCR method using the 16S rRNA gene. By analyzing its sequence and blast on the NCBI site and using the Mega7 software, the new sequence identified was deposited in the GenBank database under accession numbers MN086349 and it was registered with Nocardia coubleae strain COU 2 (Fig. 5).

\section{DISCUSSION}

Biosurfactants are extensively used in many industries thanks to their non-toxic effects. The aim of this study was to introduce biosurfactant-producing bacteria from the genus Nocardia, which has a considerable potential in biosurfactant production. The biosurfactant produced by the bacteria isolated in this study using CTAB agar test and FTIR analysis proved to have a glycolipid nature. In addition, its emulsifying activity was $100 \%$ by achieving E24\% index, indicating the potential of the bacterial biosurfactant in emulsifying the oil. In terms of surface tension lowering characteristic, it also had a strength of $35 \mathrm{mN} / \mathrm{m}$. The bio- surfactant extracted with sustainability studies revealed that it is heat resistant and can withstand salinity as well as acidic and alkaline conditions. This property can be used in various industrial or environmental conditions. Many studies are currently being conducted to isolate and identify biosurfactant-producing bacteria in the world. In these studies, various properties of biosurfactant have been investigated and the related bacterium has been introduced. For example, Mahalingam et al. ${ }^{14}$ evaluated Pseudomonas and Bacillus bacteria for the ability to produce biosurfactant, and stated that the activity of the biosurfactant isolated from Pseudomonas was higher due to the high emulsifying activity of $78 \%$ compared with $64 \%$ by Bacillus. Compared to the present study, which showed $100 \%$ activity for E24\%, the biosurfactant produced by Pseudomonas had a far lower activity. There are a limited number of studies on the genus Nocardia. In 2011, Vyas et al. ${ }^{11}$ reported N. otitidiscaviarum as the biosurfactant producer. Using FTIR analysis, they proved the glycolipid nature of the extracted biosurfactant. After 28 days of incubation, the bacterium had a maximum E24\% of about $75 \%$, which was significantly lower than the present study value. Various studies have worked on the isolation and introduction of biosurfactant-producing microorganisms. Therefore, comparing the properties 


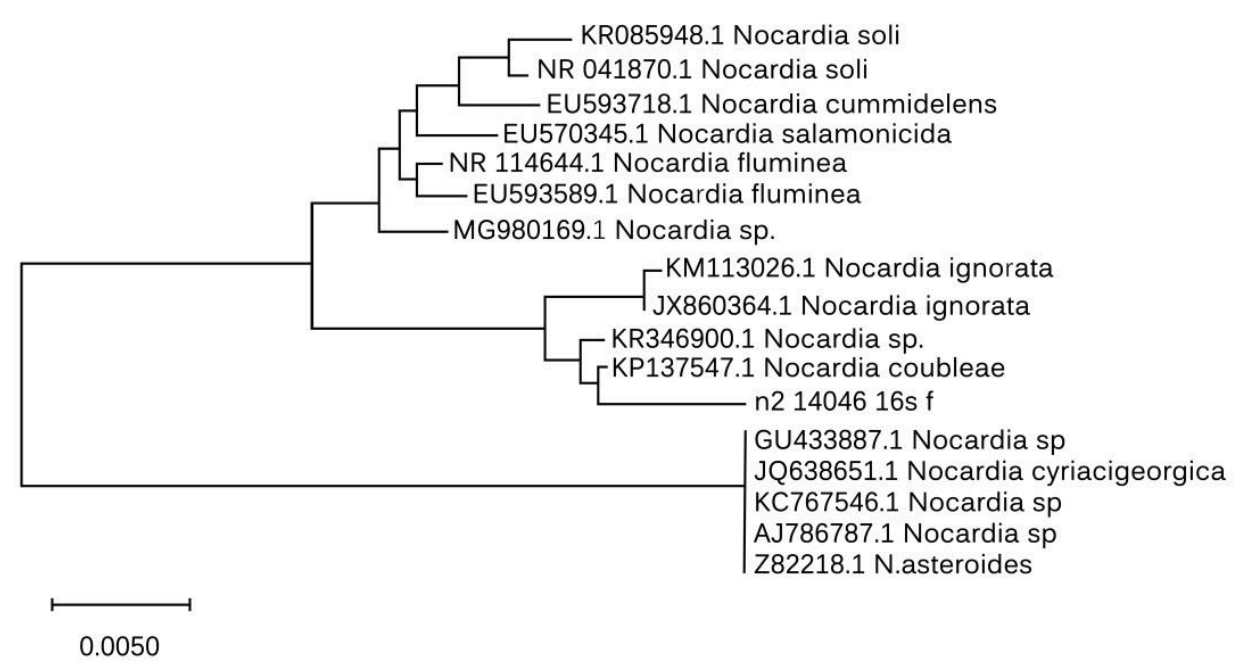

Figure 5. Neighbour-joining phylogenetic tree of strain (n2 14046) made by MEGA 7.0.

of the extracted biosurfactant in terms of surface tension lowering characteristic, emulsifying activity, stability under different temperature, salinity, acidic and alkaline $\mathrm{pH}$ conditions across different microorganisms and introducing an economically justified microorganism require further studies. The biosurfactant at a particular concentration (200 $\mu \mathrm{g} / \mathrm{ml}$ ) resulted in up to $85 \%$ removal of biofilm and hence may be appropriate for treating infections related to highly resistant pathogenic bacteria. In this study, the isolated $N$. coubleae can be a representative of the genus Nocardia in terms of the production of biosurfactant with beneficial physicochemical properties.

\section{CONCLUSIONS}

In the present study, carefully selected Nocardia spp. from soil samples in Tehran were found to be potent biosurfactant producers and were easily detected by applying screening tests such as oil displacement, CTAB agar, and measurement of surface tension along with emulsification index. Nocardia coubleae found to be the best biosurfactant producer and accordingly the adopted methodology drives forward the success of isolation, selection, and screening protocols for biosurfactant production.

\section{Conflicts of Interest}

The authors declare that there are no competing interests in this work.

\section{Ethical Approval}

This research was approved by the ethics committee of Tehran University of Medical Sciences, Tehran, Iran (Ethic of Number: IR.TUMS.SPH.REC.1396.3205).

\section{Funding/Support}

This study was supported in part by grant 34468270396 from the Tehran University of Medical Science.

\section{REFERENCES}

1. Lazzarini A, Cavaletti L, Toppo G, et al. Rare genera of actinomycetes as potential producers of new antibiotics. Antonie van Leeuwenhoek, 2000; 78(3-4):399-405.

2. El-Gendy MMA, Hawas UW, Jaspars M. Novel bioactive metabolites from a marine derived bacterium Nocardia sp. ALAA 2000. J Antibiot (Tokyo) 2008. 61(6):379-86.

3. Rahdar HA, Azadi D, Shojaei H, et al. Molecular analysis and species diversity of Nocardia in the hospital environment in a developing country, a potential health hazard. J Med Microbiol 2017; 66(3):334-41.

4. Kavitha A, Prabhakar P, Narasimhulu M, et al. Isolation, characterization and biological evaluation of bioactive metabolites from Nocardia levis MK-VL_113. Microbiol Res 2010; 165(3):199-210.

5. Garg M, Chatterje M. Isolation, characterization and antibacterial effect of biosurfactant from Candida parapsilosis. Biotechnology Reports $2018 ; 18(\mathrm{C}): \mathrm{e} 00251$.

6. Shekhar S, Sundaramanickam A, Balasubramanian T. Biosurfactant producing microbes and their potential applications: a review. Crit Rev Environ Sci Technol 2015; 45(14):1522-54.

7. Vecino X, Cruz JM, Moldes, et al. Biosurfactants in cosmetic formulations: trends and challenges. Crit Rev Biotechnol 2017; 37(7):911-23.

8. Nayarisseri A, Singh P, Singh SK. Screening, isolation and characterization of biosurfactant producing Bacillus subtilis strain ANSKLAB03. Bioinformation 2018; 14(6):304-14.

9. Walter V, Syldatk C, Hausmann R. Screening concepts for the isolation of biosurfactant producing microorganisms. In: Sen R, editor. Biosurfactants 2010: 1-13.

10. Habibnia S, Nasab MR, Heidarieh P, et al. Phenotypic characterization of Nocardia spp. isolated from Iran soil microflora. Int J Environ Health Eng 2015; 4(1):20. 
11. Vyas T, Dave B. Production of biosurfactant by Nocardia otitidiscaviarum and its role in biodegradation of crude oil. Int J Environ Sci Technol 2011; 8(2):425-32.

12. Moussa TAA, Gaber A, Abdel-Hamid SM. Mathematical model for biomass yield and biosurfactant production by Nocardia amarae. J Appl Sci Res 2006; 2:844-50.

13. Płaza GA, Zjawiony I, Banat IM. Use of different methods for detection of thermophilic biosurfactant-producing bacteria from hydrocarboncontaminated and bioremediated soils. J Petrol Sci Eng 2006; 50(1):71-7.

14. Mahalingam $P$, Sampath N. Isolation, characterization and identification of bacterial biosurfactant. Europ J Exp Biol 2014; 4(6):59-64.

15. Dhasayan A, Selvin J, Kiran S. Biosurfactant production from marine bacteria associated with sponge Callyspongia diffusa. 3 Biotech 2015; 5(4):443-54.

16. Gandhimathi R, Kiran GS, Hema TA, et al. Production and characterization of lipopeptide biosurfactant by a sponge-associated marine actinomycetes Nocardiopsis alba MSA10. Bioprocess Biosyst Eng 2009; 32(6):825-35.

17. Khopadea A, Biao R, Liu X, et al. Production and stability studies of the biosurfactant isolated from marine Nocardiopsis sp. B4. Desalination 2012; 285:198-204.

18. Gomaa EZ. Exopolysaccharide-mediated silver nanoparticles produced by Lactobacillus brevis NM101-1 as antibiotic adjuvant. Microbiology 2016; 85(2):207-19. 


\title{
Оценка антибиоплёночного потенциала биосурфактанта, выделенного из видов Nocardia
}

\author{
Али Джавади ${ }^{1}$, Мохамед Реза Поурманд ${ }^{1}$, Джавад Хамеди르 Фатеме Гаребаги $^{1}$, Зохре Басери ${ }^{3}$, \\ Абас Моровати ${ }^{1}$, Разие Мохамедзадех ${ }^{1}$, Сейед Саеед Есхраги ${ }^{1}$ \\ ${ }^{1}$ Кафедра патобиологии, Факультет общественного здравоохранения, Тегеранский университет медицинских наук, Тегеран, Иран \\ 2 Лаборатория микробных биотехнологий, Кафедра микробиологии, Факультет микробиологии, Колледж наук, Тегеранский университет, \\ Тегеран, Иран \\ ${ }^{3}$ Кафедра микробиологии, Медицинский факультет, Иранский университет медииинских наук, Тегеран, Иран
}

Адрес для корреспонденции: Сейед Саеед Есхраги, Кафедра патобиологии, Факультет общественного здравохранения, Тегеранский университет медицинских наук, Тегеран, Иран; E-mail: esraghi1398@gmail.com; Тел.: +98-2188994823

Дата получения: 17 мая 2020 Дата приемки: 14 июля $2020 \diamond$ Дата публикации: 30 июня 2021

Образец цитирования: Javadi A, Pourmand MR, Hamedi J, Gharebaghi F, Baseri Z, Morovvati A, Mohammadzadeh R, Eshraghi SS. Evaluation of anti-biofilm potential of biosurfactant extracted from Nocardia species. Folia Med (Plovdiv) 2021;63(3):392-9. doi: 10.3897/folmed.63.e54386.

\section{Резюме}

Введение: Натуральные бактериальные продукты, такие как биосурфактанты и поверхностно-активные вещества, являются важными ингредиентами, которые имеют множество применений в различных областях медицины.

Цель: Целью настоящего исследования было выделение и идентификация штаммов Nocardia с высокой продукцией биосурфактанта и антибиоплёночной активностью.

Материалы и методы: В настоящем исследовании биологическое поверхностно-активное вещество, продуцируемое видами Nocardia, было выделено и идентифицировано лабораторным методом. Сначала они были изучены, а затем проверены на их способность производить биоповерхностно-активное вещество. Испытание на растекание масла и измерения поверхностного натяжения показали, что один штамм продуцировал биоповерхностно-активное вещество. Штамм с лучшими результатами по поверхностной активности был выбран для дальнейших исследований и идентифицирован методом секвенирования гена $16 \mathrm{~S}$ рPНК. Инфракрасная спектроскопия с преобразованием Фурье (FTIR) и анализ состава показали структуру биоповерхностно-активного вещества.

Результаты: Тест на растекание масла и тест на голубой агар подтвердили присутствие биосурфактантов и внеклеточных анионных гликолипидов. Испытание Е24, проведённое с оливковым маслом, выявило сильные эмульгирующие характеристики экстрагированного биоповерхностно-активного вещества со 100\% эмульгирующей способностью. Спектр FTIR показал присутствие алифатической углеводородной цепи (липида) вместе с полисахаридным фрагментом, что подтвердило гликолипидную природу биосурфактанта. Стабильность биосурфактанта, полученного в различных условиях, была значительной. Повышение концентрации BS значительно подавляло развитие биоплёнки Pseudomonas aeruginosa.

Заключение: N. coubleae может быть представителем рода Nocardia по производству биосурфактантов с полезными физико-химическими свойствами.

\section{Ключевые слова}

биоплёнки, выделение и очистка, Nocardia, поверхностно-активные вещества, Pseudomonas aeruginosa 